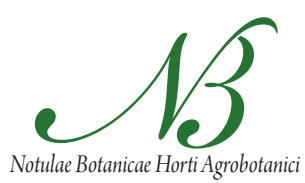

Cluj-Napoca

\title{
Biochemical and Physiological Changes in Response to Salinity in Two Durum Wheat (Triticum turgidum L.) Genotypes
}

\author{
Ezatollah ESFANDIARI', Vaghef ENAYATI, Amin ABBASI \\ University of Maragheh, Faculty of Agriculture, Department of Agronomy and Plant Breeding, Madar Square, \\ Daneshghah Avenue, Maragheh, 55181-83111, Iran; esfand1977@yahoo.com ('correspondingauthor)
}

\begin{abstract}
The effects of salt stress on the activity of antioxidative enzymes, some oxidative stress indices and $\mathrm{Na}^{+}$and $\mathrm{K}^{+}$content were studied in leaves of two durum wheat cultivars, 'Egypt 449' (salt-tolerant) and 'Syria 371' (salt-sensitive), grown under control (nutrient solution) or salt stress (nutrient solution containing $200 \mathrm{mM} \mathrm{NaCl}$ ) conditions. Leaves of control and salt-stressed plants were harvested from $10 \mathrm{days}$ old plants beyond salt treatment. The results showed significant increase for activities of antioxidant enzymes such as ascorbate peroxidase (APX) and guaiacol peroxidase (GPX), in 'Egypt 449' under salinity. At the same time, in cultivar 'Egypt 449', activity of SOD and CAT were not changed. Meanwhile, under salinity condition the activities of antioxidant enzymes such as superoxide dismutase (SOD), catalase (CAT) and GPX in cultivar 'Syria 371' was lower than control. There was no significant difference between salinity situation and control ones regarding APX activity. Salt stress elevated the amounts of malondialdehyde (MDA) in both cultivars. However, the increasing rate in 'Syria 371' was more than (four times) that of 'Egypt 449'. Membrane stability index (MSI) of both cultivars negatively influenced by salinity. This negative impact on 'Syria 371' was highlighted than on 'Egypt 449'. Hydrogen peroxide $\left(\mathrm{H}_{2} \mathrm{O}_{2}\right)$ content of salinity faced 'Syria 371' was higher than control. Both cultivars displayed increasing and decreasing trend for $\mathrm{Na}^{+}$and $\mathrm{K}^{+}$content, respectively. Moreover, $\mathrm{K}^{+} / \mathrm{Na}^{+}$ratio was decreased in both cultivars due to salinity. The studied parameters elucidated that salt resistance of 'Egypt 449' might be due to increased activity of antioxidant enzymes, low lipid peroxidation, assumingly lower changes in membrane stability index and avoidance of $\mathrm{Na}^{+}$absorption.
\end{abstract}

Keywords: antioxidant enzymes, salinity, oxidative stress, wheat

\section{Introduction}

Soil salinity is a major abiotic stress adversely affects physiological and metabolic processes, leading to diminished growth and yield (Azizpour et al., 2010). Salinity affects the availability of nutrients and water. Moreover, it induces osmotic stress; the physiological drought, which typically reduces the growth and photosynthesis in plants (Munnes and Tester, 2008). Growth reduction due to salinity is also attributed to ion toxicity and nutrient imbalance, which causes not only high sodium $\left(\mathrm{Na}^{+}\right)$and chloride $\left(\mathrm{Cl}^{-}\right)$accumulation in plants, but also antagonistically affects the uptake of essential nutrient elements such as potassium $\left(\mathrm{K}^{+}\right)$, calcium $\left(\mathrm{Ca}^{2+}\right)$ and magnesium $\left(\mathrm{Mg}^{2+}\right)$ in competition with $\mathrm{Na}^{+}$and also nitrate $\left(\mathrm{NO}_{3}{ }^{-}\right)$in contrast with $\mathrm{Cl}^{-}$(Sairam et al., 2002; Zörb et al., 2004). Salt stress in addition to the known components of osmotic stress and ion toxicity, is also manifested as an oxidative stress (Esfandiari et al., 2007a).

One of the biochemical changes encountered in plants subjected to salinity is the production of reactive oxygen species (ROS). The main sites of ROS production in the plant cell during salinity are the organelles with highly oxidizing metabolic activities or with sustained electron flow; chloroplasts, mitochondria and peroxysome (Esfandiari et al., 2007b). ROS are highly reactive and when the plant capacity for scavenging of those molecules is less than ROS production rate they can seriously disrupt normal metabolism through oxidative damages on lipids, proteins and nucleic acids (Murillo-Amador et al., 2006). Plants posses a number of antioxidant enzymes such as SOD, CAT, peroxidase (POX) that protect plant cells them from these potential cytotoxic effects (Edreva, 2005). SOD is a major scavenger of $\mathrm{O}_{2}{ }^{-}$and its enzymatic action results in the formation of $\mathrm{H}_{2} \mathrm{O}_{2}$ (Sen Gupta et al., 1983). CAT and POD catalyze the breakdown of $\mathrm{H}_{2} \mathrm{O}_{2}$. Therefore, these enzymatic systems eliminate the damaging effects of toxic oxygen species (Katsuhara et al., 2005).

Plant species adapt themselves to high salt concentrations in the soils with the compartmentation of inorganic molecules in the vacuole as well as accumulation of organic solutes in the cytoplasm and other organelles (Chinnusamy et al., 2005; Tejera et al., 2006). Cations such as $\mathrm{K}^{+}$and $\mathrm{Na}^{+}$are known to be the major inorganic elements, which provide necessary osmotic potential for water uptake by plant cells (Tejera et al., 2006). Regulation of $\mathrm{K}^{+}$uptake beside prevention of $\mathrm{Na}^{+}$entry and efflux of $\mathrm{Na}^{+}$from the cell, and futhermore sequestration of $\mathrm{Na}^{+}$in vacuole for osmotic adjustment are the common strategies for maintenance of desirable $\mathrm{K}^{+} / \mathrm{Na}^{+}$ratios in 
166

the cytosol. A high $\mathrm{K}^{+} / \mathrm{Na}^{+}$ratio in the cytosol is essential for normal cellular functions of plants (Chinnusamy et al., 2005). The accumulation of compatible solutes such as proline, glycinebetaine and soluble sugars, which are non-toxic at higher concentrations to cytoplasmic functions, allows additional water uptake from the environment and subsequently turgor maintenance (Sairam et al., 2002). These compounds regulate cellular redox potential, preserve spatial conformation of proteins and integrity of membranes stabilize the function of some fundamental biochemical routes such as oxygen evolving PS-II complex (Chinnusamy et al., 2005) and finally enhance the activity of some related enzymes to scaveng the reactive oxygen species (Chinnusamy and Zhu, 2003).

Although durum wheat cultivars are more salt sensitive than bread wheat and their yield is lower under saline soils (Munns and James, 2003); the quality requirements of pasta are only satisfied by durum. For this reason breeding new cultivars of durum wheat capable of that can be grown on saline soils is of great interest. Understanding of salt tolerance mechanism and development of salt tolerant plants can be facilitated by the use of molecular, biochemical and physiological markers/traits.

The objective of the present study was to elucidate the differential physiological and biochemical responses of a salt-tolerant and a salt-sensitive variety of durum wheat to salinity under hydroculture conditions.

\section{Material and methods}

Plant material and induction of salt stress

Seeds of two durum wheat [Triticum turgidum L. subsp. durum (Desf.) Husn.] cultivars; 'Egypt 449' (salt tolerant) and 'Syria 371' (salt sensitive) were obtained from the International Center for Agricultural Research in the Dry Areas (ICARDA). Seeds were sterilized with $0.1 \%$ SDS by stirring them for 20 minutes. Then, the seeds were washed out several times with deionized water and were germinated on filter paper at $25^{\circ} \mathrm{C}$ under dark conditions for three days. Seedlings were planted in tap water (electrical conductivity of $0.35 \mathrm{dS} / \mathrm{m}$ ) and were grown in a growth chamber at $16 \mathrm{~h}$ light: 8 bh dark photoperiod, $25^{\circ} \mathrm{C}$, relative humidity of $65 \%$ and with a light intensity of 6000 Lux. The source of light inside the growth chamber was a combination of yellow and white fluorescent lamps. Seven and fourteen days after the germination of seeds, the tap water was replaced with one-half and fullstrength Hoagland's nutrient solution (Hoagland and Arnon, 1950), respectively.

The composition of the nutrient solution in $\mathrm{mM}$ was: 1 calcium nitrate $\left.\left[\mathrm{Ca}\left(\mathrm{NO}_{3}\right)_{2}\right], 4 \mathrm{H}_{2} \mathrm{O}\right] ; 0.1$ monopotassium phosphate $\left(\mathrm{KH}_{2} \mathrm{PO}_{4}\right) ; 0.5$ potassium sulfate $\left(\mathrm{K}_{2} \mathrm{SO}_{4}\right) ; 0.5$ magnesium sulfate $\left(\mathrm{MgSO}_{4}\right)$ and in $\mu \mathrm{mol}, 10$ boric acid $\left(\mathrm{H}_{3} \mathrm{BO}_{3}\right) ; 20$ manganese chloride $\left(\mathrm{MnCl}_{2}, 4 \mathrm{H}_{2} \mathrm{O}\right) ; 0.5$ zinc sulfate $\left(\mathrm{ZnSO}_{4}, 7 \mathrm{H}_{2} \mathrm{O}\right) ; 1$ copper sulfate $\left(\mathrm{CuSO}_{4}\right.$ $\left.5 \mathrm{H}_{2} \mathrm{O}\right) ; 0.1$ molybdenum trioxide $\left(\mathrm{MoO}_{3}\right)$ and 100 iron sulfate $\left(\mathrm{FeSO}_{4} 7 \mathrm{H}_{2} \mathrm{O}\right)$. These solutions were continuously aerated by electrical pumps (Resun, AC 9904, China) and renewed every three days. The $\mathrm{pH}$ of the nutrient solution was measured by a pH (HANNA, HI9811, Hanna Instruments, Padova, Italy) and adjusted to 5.5 by adding $1 \mathrm{~N}$ sulfuric acid $\left(\mathrm{H}_{2} \mathrm{SO}_{4}\right)$.

When seedlings were four-weeks old, salt stress treatments were imposed by adding $200 \mathrm{mmol} \mathrm{NaCl}$ to the full-strength nutrient solution step by step, i.e. $25 \mathrm{mmol}$ at the first step, $25 \mathrm{mmol}$ one day later and $50 \mathrm{mmol}$ every three days to avoid osmotic shock until the final concentration of $200 \mathrm{mmol} \mathrm{NaCl}$ was achieved. A nutrient solution without $\mathrm{NaCl}$ addition served as the control.

Ten days after salinization, the leaves were sampled, incubated in liquid nitrogen and maintained at $-20^{\circ} \mathrm{C}$ until the measurement of variables. At the same time, samples for membrane stability index (MSI) assay were collected from the first fully expanded leaf (second leaf from the top) and brought to the laboratory in ice buckets.

\section{Measuring the physiological and biochemical parameters}

\section{Enzyme extraction}

For SOD, CAT and GPX extraction, leaf samples $(0.5$ g) were homogenized in ice-cold $0.1 \mathrm{M}$ phosphate buffer $(\mathrm{pH} 7.5)$ containing $0.5 \mathrm{mM}$ EDTA with pre-chilled pestle and mortar. Each homogenate was transferred to centrifuge tubes and was centrifuged at $4^{\circ} \mathrm{C}$ in Beckman refrigerated centrifuge for $15 \mathrm{~min}$ at $15000 \times \mathrm{g}$. The supernatant was used for enzyme activity assay (Esfandiari et al., 2007b).

For APX extraction, leaf samples $(0.5 \mathrm{~g})$ were homogenized in ice-cold $0.1 \mathrm{M}$ phosphate buffer $(\mathrm{pH} 7.5)$ containing $0.5 \mathrm{mM}$ EDTA, $2 \mathrm{mM}$ ascorbate (AsA) and 5\% polyvinylpyrrolidin (PVP 6000) with pre-chilled pestle and mortar. The other stages were similar to the extraction of other enzymes (Esfandiari et al., 2007b).

\section{Enzyme activity assay}

SOD activity was estimated by recording the decrease in absorbance of superoxide-nitro blue tetrazolium complex by the enzyme (Sairam et al., 2002). About $3 \mathrm{ml}$ of reaction mixture, containing $0.1 \mathrm{ml}$ of $200 \mathrm{mM}$ methionine, $0.01 \mathrm{ml}$ of $2.25 \mathrm{mM}$ nitro-blue tetrazolium (NBT), $0.1 \mathrm{ml}$ of $3 \mathrm{mM}$ EDTA, $1.5 \mathrm{ml}$ of $100 \mathrm{mM}$ potassium phosphate buffer, $1 \mathrm{ml}$ distilled water and $0.05 \mathrm{ml}$ of enzyme extraction, were taken in test tubes from each enzyme sample. Two tubes without enzyme extract were taken as control. The reaction was started by adding $0.1 \mathrm{ml}$ riboflavin $(60$ $\mu \mathrm{M}$ ) and placing the tubes below a light source of two 15 W florescent lamps for $15 \mathrm{~min}$. Reaction was stopped by switching off the light and covering the tubes with black cloth. Tubes without enzyme developed maximal color. A non-irradiated complete reaction mixture which did not develop color served as blank. Absorbance was recorded at $560 \mathrm{~nm}$ and one unit of enzyme activity was taken as the 
quantity of enzyme which reduced the absorbance reading of samples to $50 \%$ in comparison with tubes lacking enzymes.

CAT activity was measured according to Aebi (1984). Reaction mixture contained $100 \mathrm{mM}$ potassium phosphate buffer ( $\mathrm{pH} 7), 75 \mathrm{mM} \mathrm{H}_{2} \mathrm{O}_{2}$, enzyme extract and distilled water. Reaction started by adding $\mathrm{H}_{2} \mathrm{O}_{2}$ and the decrease in absorbance was recorded at $240 \mathrm{~nm}(\varepsilon=36$ $\mathrm{mM}^{-1} \mathrm{~cm}^{-1}$ ) for $1 \mathrm{~min}$. Enzyme activity was computed by calculating the amount of $\mathrm{H}_{2} \mathrm{O}_{2}$ decomposed.

APX activity was measured according to Yoshimura $e t$ al.(2002) by monitoring the rate of ascorbate oxidation at $290 \mathrm{~nm}\left(\varepsilon=2.8 \mathrm{mM}^{-1} \mathrm{~cm}^{-1}\right)$. The reaction mixture contained $25 \mathrm{mM}$ phosphate buffer ( $\mathrm{pH} 7$ ), $0.1 \mathrm{mM}$ EDTA, $1 \mathrm{mM} \mathrm{H}_{2} \mathrm{O}_{2}, 0.25 \mathrm{mM}$ reduced ascorbate (AsA) and the enzyme sample. No change in absorption was found in the absence of AsA in the test medium.

GPX activity was measured according to Panda et al.(2003). Reaction mixture contained $100 \mathrm{mM}$ potassium phosphate buffer ( $\mathrm{pH}$ 7), $0.1 \mathrm{mM}$ EDTA, $5 \mathrm{mM}$ guaiacol, $15 \mathrm{mM} \mathrm{H}_{2} \mathrm{O}_{2}$ and enzyme sample. The enzyme produced a colorful product by using $\mathrm{H}_{2} \mathrm{O}_{2}$ and guaiacol as substrates. The absorbance of the product was monitored at $470 \mathrm{~nm}$ $\left(\varepsilon=26.6 \mathrm{mM}^{-1} \mathrm{~cm}^{-1}\right)$, and peroxidase activity was expressed as units $/ \mathrm{mg}$ protein. min.

MDA was measured by colorimetric method. $0.5 \mathrm{~g}$ of leaf samples were homogenized in $5 \mathrm{ml}$ of distilled water. An equal volume of $0.5 \%$ thiobarbituric acid (TBA) in $20 \%$ trichloroacetic acid (TCA) solution was added and the sample incubated at $95^{\circ} \mathrm{C}$ for $30 \mathrm{~min}$. The reaction stopped by putting the reaction tubes in an ice bath. The samples were then centrifuged at $10000 \times \mathrm{g}$ for $30 \mathrm{~min}$. The supernatant was removed, absorption read at $532 \mathrm{~nm}$, and the amount of nonspecific absorption at $600 \mathrm{~nm}$ read and subtracted from this value. The amount of MDA present was calculated from the extinction coefficient $(\varepsilon=155$ $\mathrm{mM}^{-1} \mathrm{~cm}^{-1}$ ) (Stewart and Bewley, 1980).

Hydrogen peroxide levels were determined according to Sergive et al. (1997). Leaf tissues (0.5 g) were homogenized in ice bath with $5 \mathrm{ml} 0.1 \%(\mathrm{w} / \mathrm{v}) \mathrm{TCA}$. The homogenate was centrifuged at $12000 \times \mathrm{g}$ for $15 \mathrm{~min}$ and $0.5 \mathrm{ml}$ of the supernatant was added to $0.5 \mathrm{ml} 10 \mathrm{mM}$ potassium phosphate buffer ( $\mathrm{pH} 7.0)$ and $1 \mathrm{ml} 1 \mathrm{M} \mathrm{KI}$. The absorbancy of supernatant was read at $390 \mathrm{~nm}$. The content of $\mathrm{H}_{2} \mathrm{O}_{2}$ was given on standard curve.

Protein content of samples was determined by method of Bradford (1976). Bovine serum albumin was used as a standard.

MSI was determined by recording the electrical conductivity of leaf ions leaching in double distilled water (Sairam and Srivastava, 2002). Leaf samples (0.1 g) were taken in test tubes containing $10 \mathrm{ml}$ of double distilled water in two sets. One set was kept at $40^{\circ} \mathrm{C}$ for $30 \mathrm{~min}$ and another set at $100^{\circ} \mathrm{C}$ in boiling water bath for $15 \mathrm{~min}$ and their respective electrical onductivities, $\mathrm{C} 1$ and $\mathrm{C} 2$, were measured by a pH-EC meter (HANNA, HI9811, Hanna
Instruments, Padova, Italy). Membrane stability index was calculated by the following formula:

$\mathrm{MSI}=[1-(\mathrm{C} 1 / \mathrm{C} 2)] \times 100$

Potassium and sodium contents were measured by flame photometry method. Leaf samples were dried and pulverized. Powdered leaf materials $(1 \mathrm{~g})$ were kept at $560^{\circ} \mathrm{C}$ for $4 \mathrm{~h}$ for ash preparation. To these samples, $20 \mathrm{ml}$ $1 \mathrm{~N} \mathrm{HCl}$ was added and the mixtures were heated at $90^{\circ} \mathrm{C}$ to drive off the hydrochloric acid. The digested ash was dissolved in $100 \mathrm{ml}$ distilled water and then filtered. The filtrate was stored in a refrigerator until analysis. Concentrations of potassium and sodium ions were estimated by referring to $0,5,10,20$, and $30 \mathrm{ppm}$ standard working solution. The test solution was diluted if its signal was above that of the highest standard. Content of the elements were calculated by using the following equation (Bandehhag et al., 2004):

\section{$\mathrm{E}=[(\mathrm{C} \times \mathrm{V} \times \mathrm{D}) /(\mathrm{M} \times 106)] \times 100$}

Where $\mathrm{E}$ is the element (either potassium or sodium) content of the test sample, expressed in \%. C is the element mass of the test solution, expressed in $\mathrm{mg} / \mathrm{l}$, read from the calibration graph. $\mathrm{V}$ is the volume, in $\mathrm{ml}$, of the digested solution $(\mathrm{V}=100)$. $\mathrm{D}$ is the dilution factor of the test solution carried out during the measurement step. $\mathrm{M}$ is the mass, in $\mathrm{g}$, of the test sample used in the procedure.

\section{Statistical analysis}

All physiological and biochemical parameters were recorded with five replications. The data were analyzed with MSTATC software. Mean comparison were carried out by LSD method.

\section{Results and discussion}

The results showed that under salinity condition, the activity of antioxidant enzymes such as SOD, CAT and GPX in cultivar 'Syria 371' were lower than control (Fig. $1 \mathrm{~A}, \mathrm{~B}$ and C). Meanwhile, there was no significant difference between salinity situation and control ones regarding APX activity (Fig. 1D). At the same time, in 'Egypt 449', the activity of SOD and CAT were unchanged (Fig. 1A and B). Contrarily, APX and GPX showed significantly increased activity under salinity compared to control treatment (Fig. $1 \mathrm{C}$ and D).

MDA amount significantly increased due to salinity in both studied cultivars. Athough this increase in the case of 'Syria 371' was approximately four times higher than that of 'Egypt 449' (Fig. 2A). MSI of both cultivars were negatively influenced by salinity. This negative impact on 'Syria 371' was highlighted than on 'Egypt 449' (Fig. 2B). $\mathrm{H}_{2} \mathrm{O}_{2}$ content of salinity faced 'Syria 371 ' was higher than control. However, its content was not affected in 'Egypt 449' (Fig. 2C).

In both cultivars, salinity treatment led to the increased $\mathrm{Na}^{+}$content. However, this increase in the case of 'Syria 371' was nearly three-times higher than 'Egypt 449' (Fig. 


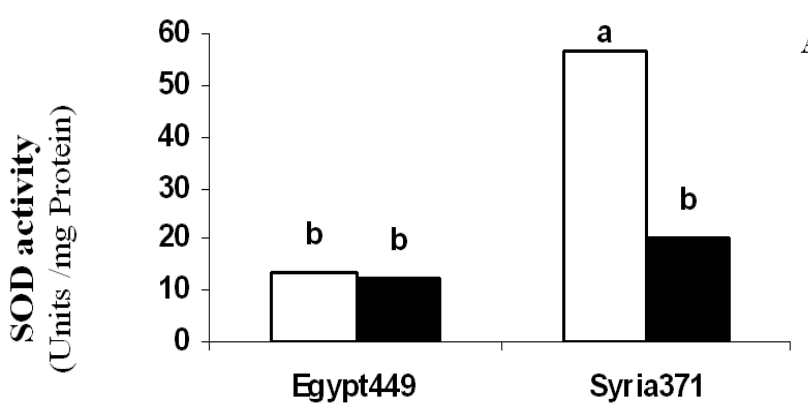

A
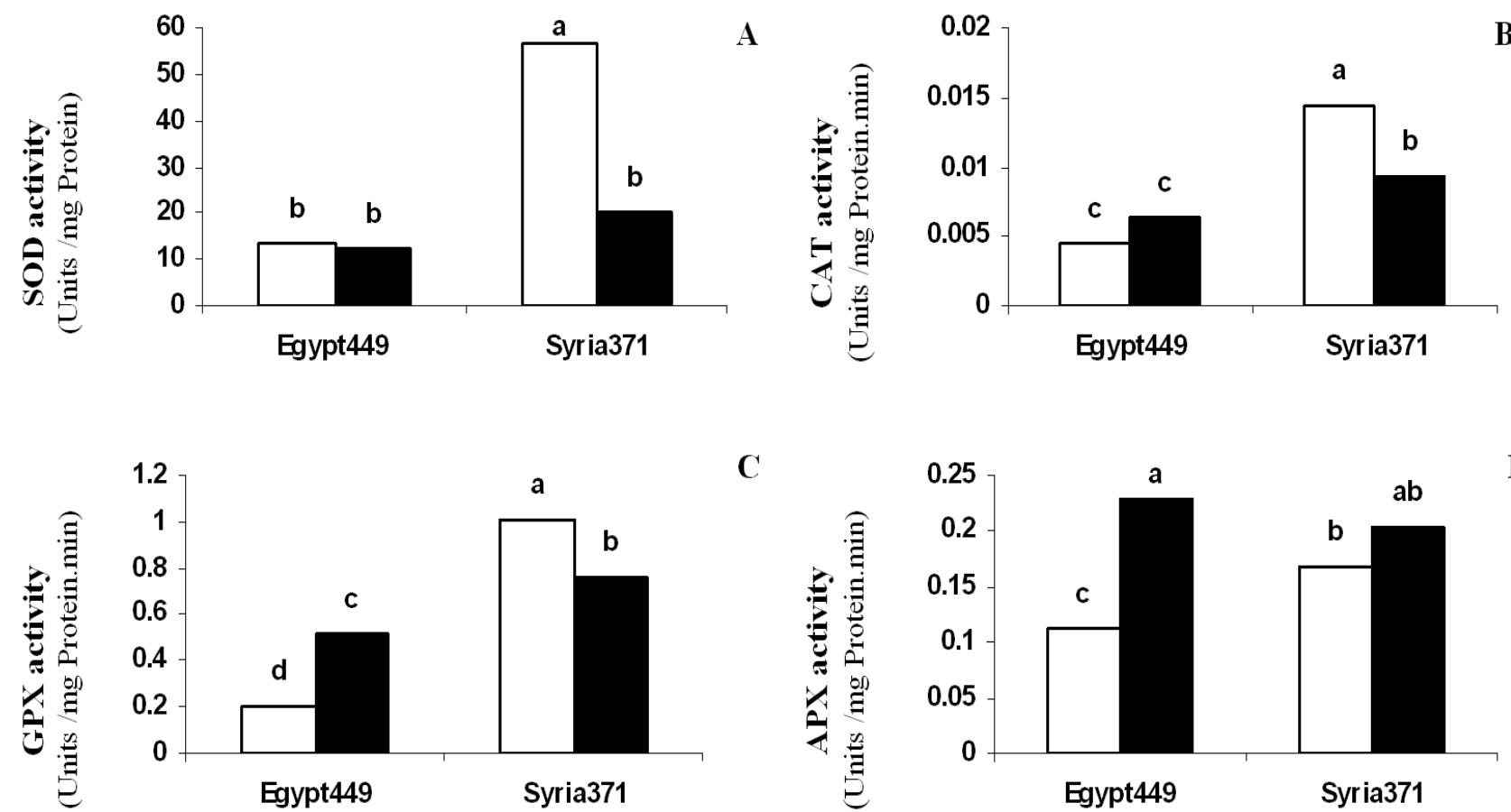

C
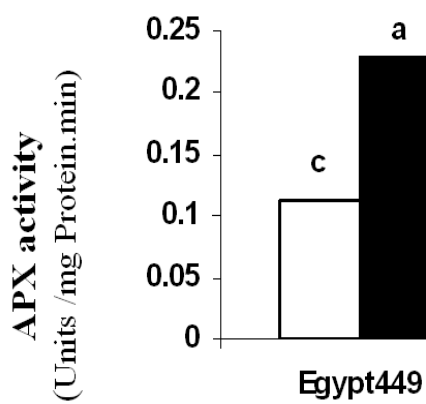

D

Fig. 1. The effect of salinity on antioxidant enzymes activity in two wheat cultivars. A) SOD, B) CAT, C) GPX and D) APX;

$\square$ Control; - Salinity
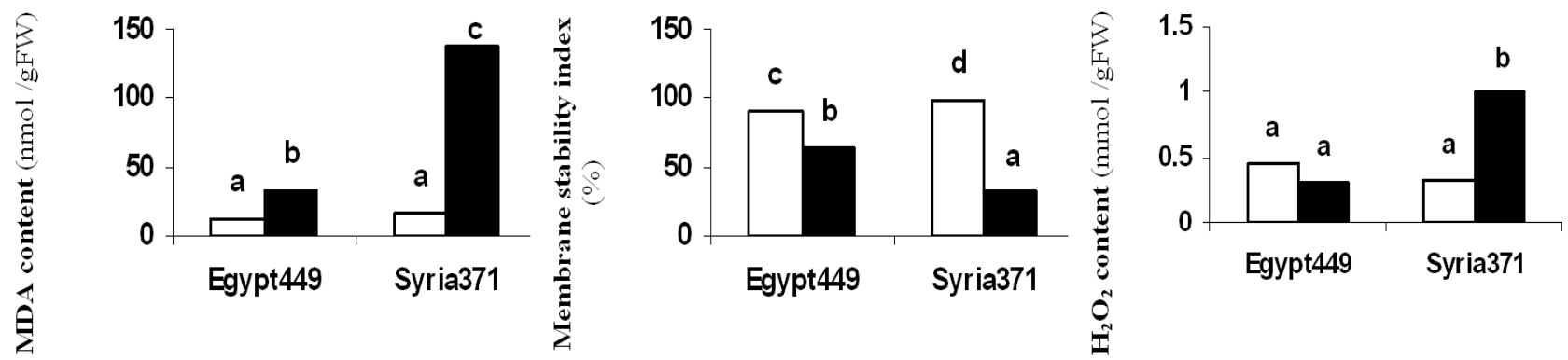

Fig. 2. The effect of salinity on malondialdehyde content (A), membrane stability index (B) and Hydrogen Peroxide content (C)

in two durum wheat cultivars; $\square$ Control; - Salinity

3A). Moreover, salinity adversely affected $\mathrm{K}^{+}$content in both cultivars (Fig. 3B). $\mathrm{K}^{+} / \mathrm{Na}^{+}$ratio of both cultivars reduced via salinity (Fig. 3C). However, there was no statistical difference between cultivars considering this ratio.

As previously understood, salinity intensity goes to reduced water availability and/or absorption and hence lowered leaf turgor and finally leads to stomata closure (Azizpour et al., 2010). Stomata closure influences $\mathrm{CO}_{2}$ acquisition and cause fluctuations and im-balances in ongoing light reactions and $\mathrm{CO}_{2}$ fixation stage (Esfandiari et al., 2007b). The final outcome of these abnormal conditions would be reduced $\mathrm{NADP}^{+} / \mathrm{NADPH}, \mathrm{H}^{+}$ratio and increased ROS production (Esfandiari et al., 2011). Mehler cycle is the most efficient intrinsic mechanism for diminished production and coping with ROS molecules (Asada, 2000). SOD activity showed declining pattern in 'Syria 371' (Fig. 1A). It is likely that the lowest SOD activity under salinity might be the main factor for intense membrane damage and increased MDA content and oxidative stress (Fig. 2A and C). Reduced SOD activity follows by the accumulation of $\mathrm{O}_{2}{ }^{-}$in leaf cells and consequently results is the blockage of CAT and peroxidases activity (Fridivich, 1989). Any increase in above mentioned cycles activity under salinity goes to stability in cell mechanisms and reduced occurrence of oxidative stress (Edreva, 2005, Esfandiari et al., 2011). In 'Syria 371', in spite of oxidative stress, SOD activity was not increased (Fig. 1A). Mehler cycle operation under stress conditions help the plant to activate the xanthophyl cycle by acidification of lumen space (Ort, 2002). Furthermore, in 'Syria 371', CAT and GPX activities were significantly decreased (Fig. 1B and C). These enzymes have the potential to neu- 

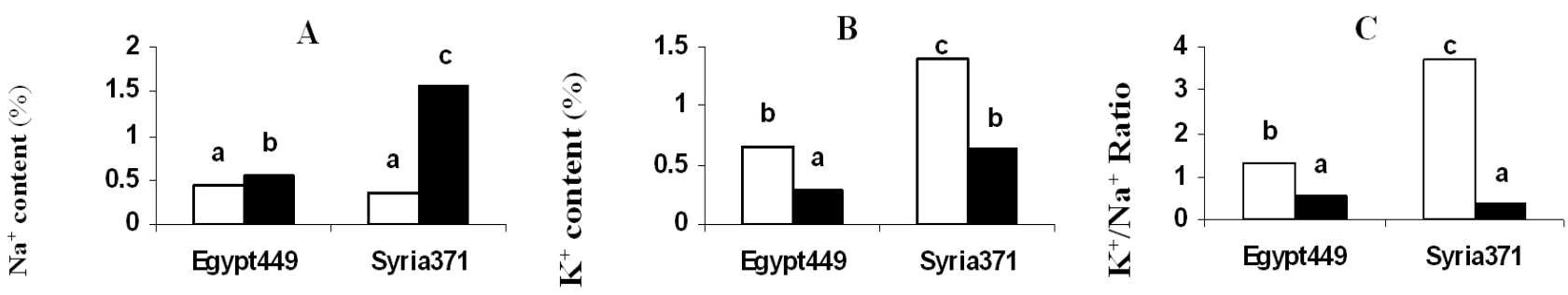

Fig. 3. The effect of salinity on $\mathrm{Na}^{+}(\mathrm{A}), \mathrm{K}^{+}(\mathrm{B})$ and $\mathrm{K}^{+} / \mathrm{Na}^{+}(\mathrm{C})$ in two durum wheat cultivars; $\square$ Control; • Salinity

tralize $\mathrm{H}_{2} \mathrm{O}_{2}$ via its conversion to $\mathrm{H}_{2} \mathrm{O}$ molecules (Edreva, 2005, Ahmed et al., 2009). Any reduction in $\mathrm{H}_{2} \mathrm{O}_{2}$ scavenging enzymes activity causes the accumulation of these oxidants in leaf cells.Ionic stress induced by Salinity conditions i.e. intensified absorption of $\mathrm{Na}^{+}$and $\mathrm{Cl}^{-}$antagonistically affect $\mathrm{K}^{+}, \mathrm{Ca}^{2+}$ and $\mathrm{Mg}^{2+}$ absorbtion and metabolism (El-Hendawy et al., 2005; Mansour et al., 2005; MurilloAmador et al., 2006). There is strong evidence that plants have potential to cope with toxic levels of saline sodic ions via accumulation of those ions in vacuole or apoplast and furthermore, employ them as osmoticum molecules for cell turgor maintenance (Yeo and Flowers, 1983, Cramer et al., 1994, Leidi and Saiz, 1997). Similarly, Munns and James (2003) reported that several salt-tolerant tetraploid wheat genotypes do indeed accumulate very high leaf sodium levels. These genotypes may have a special ability to tolerate high internal levels of sodium. The higher concentration of sodium may results from the greater capability for compartmentation of this ion in the vacuoles.

Other scientists claim that tolerant plants prevent $\mathrm{Na}^{+}$ and $\mathrm{Cl}^{-}$absorbtion and/or translocation. $\mathrm{Na}^{+}$content of 'Syria 371' and 'Egypt 449' meaningfully increased due to salinity (Fig. 3A). However, intensified oxidative damage in 'Syria 371' might be in consequence of $\mathrm{Na}^{+}$and $\mathrm{Cl}^{\text {' toxic }}$ levels. This means that 'Syria 371' was not able to combat toxic levels of $\mathrm{Na}^{+}$accumulation in cytosol. Meanwhile, 'Egypt 449' was capable to prevent toxic accumulation of $\mathrm{Na}^{+}$ion in its aerial parts and $\mathrm{Na}^{+}$content of plant was like normal condition (Fig. 3A). At the same time, in both cultivars, $\mathrm{K}^{+} / \mathrm{Na}^{+}$ratio was low mainly due to lowered $\mathrm{K}^{+}$ content (Fig. 3C).

In conclusion, the data obtained from the present experiment revealed that 'Syria 371' showed higher oxidative stress demonstrations compared to 'Egypt 449' largely due to the low activity of antioxidant enzymes and high $\mathrm{Na}^{+}$ accumulation. Furthermore, the results showed that those plants were able to escape the ionic toxicity under saline sodic conditions via scavenging of ROS molecules and concomitantly controlled $\mathrm{Na}^{+}$absorption and translocation. Those capabilities potentiate the plants survival and productivity under stressful conditions.

\section{Acknowledgements}

The reported study was supported and financially backed by research chancellorship at University of Maragheh.

\section{References}

Aebi H (1984). Catalase in vitro. Method of Enzymology 105: 121-126.

Ahmed P, Jaleel C, Azooz M, Gowher N (2009). Generation of ROS and non-enzymatic antioxidants during abiotic stress in plants. Botany Research International 2:11-20.

Asada K (2000). The water-water cycle as alternative photon and electron sinks. Phill Trans R Soc Lond B 355:1419-1431.

Azizpour K, Shakiba MR, Khosh Kholgh Sima N, Alyari H, Moghaddam M, Esfandiari E, Pessarakli M (2010). Physiological response of spring durum wheat genotypes to salinity. Journal of Plant Nutrition 33:859-873.

Bandehhag A, Kazemi H, Valizadeh M, Javanshir A (2004). Salt tolerance of spring wheat (Triticum aestivum L.) cultivars during vegetative and reproductive growth. Iranian Journal of Agriculture Science 35:61-71. (in Persian)

Bradford MM (1976) A rapid and sensitive method for the quantitation of microgram quantities of protein utilizing the principle of protein-dye binding. Analytical Biochemistry 72:248-254.

Chinnusamy V, Zhu JK (2003). Plant salt tolerance. Topics in Current Genetics 4:241-270.

Chinnusamy V, Jagendorf A, Zhu JK (2005). Understanding and improving salt tolerance in plants. Crop Science 45:437448.

Cramer GR, Alberico GJ, Schmidt C (1994). Salt tolerance is not associated with the sodium accumulation of two maize hybrids. Australian Journal of Plant Physiology 21:675692.

Edreva A (2005). Generation and scavenging of reactive oxygen species in chloroplasts: A submolecular approach. Agriculture, Ecosystems and Environment 106:119-133.

El-Hendawy SE, Hu Y, Schmidhalter U (2005). Growth, ion content, gas exchange, and water relations of wheat genotypes differing in salt tolerances. Australian Journal of Agricultural Research 56:123-134.

Esfandiari E, Javadi A, Shokrpour M, Shekari F (2011). The effect of salt stress on the antioxidant defense mechanisms on wheat seedling. Fresenius Environmental Bulletin (in press).

Esfandiari E, Shekari F, Shekari F, Esfandiari M (2007a). The effect of salt stress on antioxidant enzymes activity and lipid peroxidation on the wheat seedling. Notulae Botanicae 
170

Horti Agrobotanicae Cluj-Napoca 35:48-56.

Esfandiar E, Shakiba MR, Mahboob S, Alyari H, Toorchi M (2007b). Water stress, antioxidant enzyme activity and lipid peroxidation in wheat seedling. Journal of Food, Agriculture and Environment 5:148-153.

Fridovich I (1989). Superoxide dismutase: An adaptation to a paramagnetic gas. The Journal of Biological Chemistry 264:7761-7764.

Hoagland DR, Arnon DI (1950). The water culture method for growing plants without soil. California Agricultural Experiment Station Circular, No. 347. Berkely, CA: University of California.

Katsuhara M, Otsuka T, Ezaki B (2005). Salt stress induced lipid peroxidation is reduced by glutathione $S$-transferase, but this reduction of lipid peroxidase is not enough for a recovery of root growth in arabidobsis. Plant Science 169:369-373.

Leidi EO, Saiz JF (1997). Is salinity tolerance related to $\mathrm{Na}^{+}$ accumulation in upland cotton (Gossypium hirsutum) seedlings? Plant and Soil 190:67-75.

Mansour MMF, Salama K, Ali F, Abou Hadid A (2005). Cell and plant responses to $\mathrm{NaCl}$ in Zea mays L. cultivars differing in salt tolerance. General and Applied Plant Physiology 31:2941.

Munns R, James R (2003). Screening methods for salinity tolerance: A case study with tetraploid wheat. Plant and Soil 253:201-218.

Munns R, Tester M (2008). Mechanism of salinity tolerance. Annual Review of Plant Biology 59:651-681.

Murillo-Amador B, Jones HG, Kaya C, Aguilar RL, GarciaHernandez JL, Troyo-Dieguez E, Avila-Serrano NY, RuedaPuente E (2006). Effects of foliar application of calcium nitrate on growth and physiological attributes of cowpea (Vigna unguiculata L. Walp.) grown under salt stress. Environmental and Experimental Botany 58:188-196.
Ort D (2001). When there is too much light? Plant Physiology 125:29-32.

Panda S, Singha L, Khan M (2003). Does aluminium phytotoxicity induce oxidative stress in greengram (Vigna radiate)? Bulgarian J Plant Physiology 29:77-86.

Sairam RK, Rao KV, Srivastava GC (2002). Differential response of wheat genotypes to long term salinity stress in relation to oxidative stress, antioxidant activity and osmolyte concentration. Plant Science 163:1037-1046.

Sen Gupta A, Webb RP, Holaday AS, Allen RD (1993). Overexpression of superoxide dismutase protects plants from oxidative stress. Plant Physiology 103:1067-1073.

Stewart R, Bewley J (1980). Lipid peroxidation associated aging of soybean axes. Plant Physiology 65:245-248.

Tejera NA, Soussi M, Lluch (2006). Physiological and nutritional indicators of tolerance to salinity in chickpea plants growing under symbiotic conditions. Environmental and Experimental Botany 58:17-24.

Yeo AR, Flowers C (1983). Varietal differences in the toxicity of sodium-ions in rice leaves. Physiologia Plantarum 59:189195.

Yoshimura K, Yabute Y, Ishikawa T, Shigeoka S (2000). Expression of spinach ascorbate peroxidase isoenzymes in response to oxidative stresses. Plant Physiology 123:223233.

Zörb C, Schmitt S, Neeb A, Karl S, Linder M, Schubert S (2004). The biochemical reaction of maize (Zea mays L.) to salt stress is characterized by a mitigation of symptoms and not by a specie adaptation. Plant Science 167:91-100. 